\title{
The distribution of the spectral bat, Vampyrum spectrum, reaches the Southern Pantanal
}

\author{
Maurício Silveira ${ }^{1,4}$, Roberto Lobo Munin ${ }^{1}$, Walfrido Moraes Tomás ${ }^{2}$, Erich Fischer ${ }^{3}$, \\ Marcelo Oscar Bordignon ${ }^{3} \&$ Guilli de Almeida Silveira ${ }^{3}$ \\ ${ }^{1}$ Programa de Pós-graduação em Ecologia e Conservação, Universidade Federal de Mato Grosso do Sul - UFMS, \\ CEP 79070-900, Campo Grande, MS, Brasil \\ ${ }^{2}$ Laboratório de Vida Selvagem, Embrapa Pantanal, CEP 79320-900, Corumbá, Brasil \\ ${ }^{3}$ Departamento de Biologia, Universidade Federal de Mato Grosso do Sul - UFMS, \\ CEP 79070-900, Campo Grande, MS, Brasil \\ ${ }^{4}$ Corresponding author: Maurício Silveira,e-mail: maursilv@yahoo.com.br
}

SILVEIRA, M., MUNIN, R.L., TOMÁS, W.M., FISCHER, E., BORDIGNON, M.O. \& SILVEIRA, G.A. The distribution of the spectral bat, Vampyrum spectrum, reaches the southern Pantanal. Biota Neotrop. 11(1): http://www.biotaneotropica.org.br/v11n1/en/abstract?article+bn02511012011.

Abstract: The largest New World bat, Vampyrum spectrum, is a locally rare top predator, which occurs from Mexico to South America. Here, we report for the first time its occurrence in the southern Pantanal floodplain, basing our records on specimens that are also the first to be reported for the State of Mato Grosso do Sul, Brazil. We conducted bat surveys in two sites $120 \mathrm{~km}$ apart, in the Aquidauana and Nhecolândia regions. Among 2,498 bat captures, two individuals of $V$. spectrum were mist-netted, one at each site. These records expand southward the distribution range of $V$. spectrum, and in addition to other records in the Northern Pantanal border and Bolivia support that $V$. spectrum is widely distributed in the upper Paraguay basin.

Keywords: Chiroptera, wetlands, Paraguay river basin, Mato Grosso do Sul, Phyllostominae.

SILVEIRA, M., MUNIN, R.L., TOMÁS, W.M., FISCHER, E., BORDIGNON, M.O. \& SILVEIRA, G.A. A distribuição do morcego espectral, Vampyrum spectrum, atinge o Pantanal sul. Biota Neotrop. 11(1): http:// www.biotaneotropica.org.br/v11n1/pt/abstract?article+bn02511012011.

Resumo: O maior morcego do Novo Mundo, Vampyrum spectrum, é um predador de topo localmente raro que ocorre do México à América do Sul. Reportamos aqui pela primeira vez sua ocorrência na região sul da planície inundável do Pantanal, tomando como base espécimes que também são os primeiros registrados para o Estado de Mato Grosso do Sul, Brasil. Realizamos inventários em dois sítios distantes 120 km, nas regiões de Aquidauana e Nhecolândia. Dentre 2498 capturas de morcegos, dois indivíduos de V. spectrum foram registrados, um em cada sítio. Esses registros expandem a distribuição de $V$. spectrum para o sul, e somados a outros registros na borda Norte do Pantanal e na Bolívia sustentam que V. spectrum é amplamente distribuída na bacia do alto Paraguai. Palavras-chave: Chiroptera, áreas úmidas, bacia do rio Paraguai, Mato Grosso do Sul, Phyllostominae. 


\section{Introduction}

The spectral bat, Vampyrum spectrum (Linnaeus, 1758), is the largest New World bat. Its body weight varies from 135 to $230 \mathrm{~g}$, the forearm length ranges from 88 to $115 \mathrm{~mm}$, and the wing span may reach 1 m (Navarro \& Wilson 1982, Nowak 1994). Based on scarce published data, V. spectrum is mainly carnivore and preys on birds, rodents, and small bats as well. However, its diet also includes insects and fruits (Gardner 2007, Navarro \& Wilson 1982, Bonato et al. 2004, Vargas-Espinoza et al. 2004, Discher et al. 2009). Vampyrum spectrum is locally rare and widely distributed from southern Mexico to the central region of South America, with known records in Colombia, Ecuador, Guyana, Peru, Venezuela, Bolivia, and Brazil (Navarro \& Wilson 1982, Emmons \& Feer 1997, Vargas-Espinoza et al. 2004, Acosta \& Azurduy 2006). To date, the southernmost record of V. spectrum is at $18^{\circ} 20^{\prime} \mathrm{S}$, in the Chiquitana Forest region, Bolivia (Acosta \& Azurduy 2006). The condition of being a top predator occurring at low densities increases its vulnerability to local extinctions, and led to classification of $V$. spectrum as a nearly threatened species by the International Union for Conservation of Nature (Aguirre et al. 2008).

Most records of $V$. spectrum in Brazil come from the Amazon rainforest, in the States of Acre, Amazonas, Amapá, Mato Grosso, Pará, Rondônia, Roraima, and Tocantins (Bernard 2001, Nogueira et al. 2007, Discher et al. 2009). One record in Northern Pantanal floodplain (Eisenberg \& Redford 1999) and another in its northern upland border (Vieira 1955) indicate the occurrence of $V$. spectrum in the Pantanal. However, multiple records are still needed for sustaining that it occurs widely in the floodplain. We report here the first records of $V$. spectrum in the southern Pantanal floodplain, and in the State of Mato Grosso do Sul as well, which significantly expand southward the distribution range of the species.

\section{Material and Methods}

Two individuals of Vampyrum spectrum were mist-netted during bat surveys at Campo Lourdes (19 $33^{\circ} \mathrm{S}$ e $\left.55^{\circ} 35^{\prime} \mathrm{W}\right)$ and Nhumirim ( $18^{\circ} 59^{\prime} \mathrm{S}$ e $56^{\circ} 37^{\prime} \mathrm{W}$ ) ranches, in the Aquidauana and Nhecolândia regions of southern Pantanal, respectively. Climate is Aw of Köppen, with average annual temperatures ranging from 20 to $27{ }^{\circ} \mathrm{C}$, and annual precipitation from 800 to $1400 \mathrm{~mm}$. Physiognomic types comprise floodable grasslands, gallery forests, open woodland savannas, deciduous and semideciduous forests named "cordilheiras" - surrounding temporary or permanent lagoons (Araujo \& Sazima 2003). The total netting efforts in Campo Lourdes and Nhumirim were 97632 and 96646 h.m², respectively.

\section{Results and Discussion}

Among 1931 bat individuals of 31 species sampled in Campo Lourdes, it was captured one adult male of V. spectrum at 23:30 hours, on August 29 ${ }^{\text {th }}, 2008$. The specimen presented developed testicles and forearm length of $114 \mathrm{~mm}$. After inspection, this individual was released in the same place of the capture. At Nhumirim, one non-reproductive female of $V$. spectrum (Figure 1) was recorded among 567 sampled bats of 21 species. It was captured at 00:00 hour on February $20^{\text {th }}, 2010$. Its forearm measured $109 \mathrm{~mm}$. This individual was collected and deposited as voucher in the Embrapa Pantanal's Vertebrate Reference Collection (M-CPAP-307), representing the only specimen of $V$. spectrum collected in the State of Mato Grosso do Sul.

The two individuals were captured in latitudes higher than that of Chiquitana Forest in Bolivia (Acosta \& Azurduy 2006), expanding the geographical distribution of V. spectrum towards southern (Figure 2).
The two records were about $120 \mathrm{~km}$ distant from each other, in the western and eastern regions of the Pantanal in Mato Grosso do Sul. Our records added to those obtained in the northern Pantanal (Vieira 1955, Eisenberg \& Redford 1999) and in Bolivia (Acosta \& Azurduy 2006) support that $V$. spectrum is widely distributed in the upper Paraguay basin. The captures of only two individuals of $V$. spectrum among more than 10,000 bats already surveyed by us in the southern Pantanal indicate that this species is locally rare in the floodplain, as it is elsewhere (Emmons \& Feer 1997, Sampaio et al. 2003).

The records of $V$. spectrum reported in the upper Paraguay basin were obtained in forest habitats. Vieira (1955) collected one specimen in riparian forest, and Acosta \& Azurduy (2006) collected two specimens at the border of a forest corridor associated to cultivated pasture areas. Our records were obtained in the typical Pantanal "cordilheiras", which are interconnected forest corridors and patches located in non-floodable terrain. These records, therefore, support that $V$. spectrum is able to

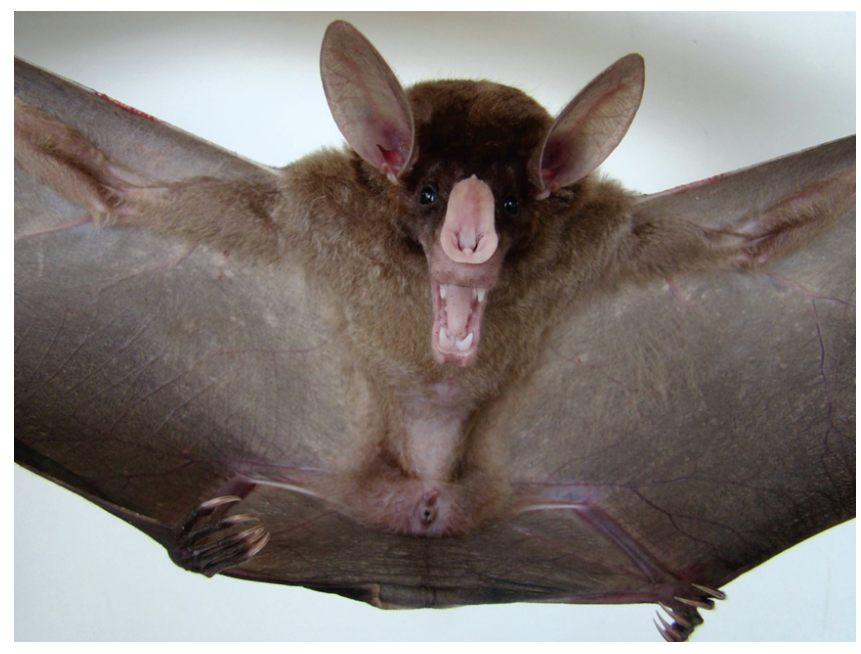

Figure 1. Vampyrum spectrum (Phyllostomidae) captured in the Nhumirim farm, Southern Pantanal, Mato Grosso do Sul, Brazil.

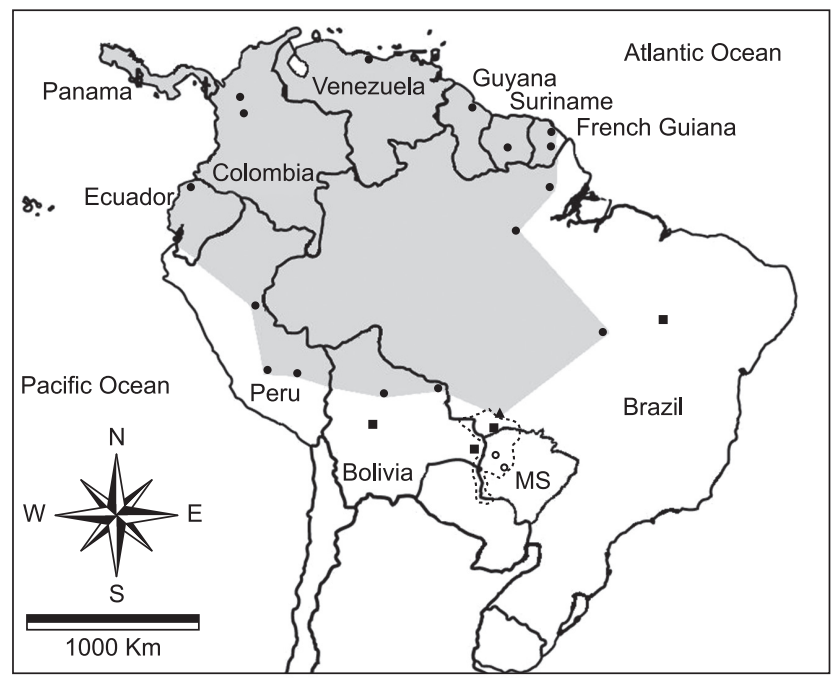

Figure 2. Distribution of Vampyrum spectrum (Phyllostomidae) in South America. Gray area encircles marginal localities compiled by Gardner (2007), indicated by black circles and black triangle for the Vieira's (1955) record. Additional records, not included in Gardner (2007), are from Bolivia (Acosta \& Azurduy 2006), northern Pantanal (Eisenberg \& Redford 1999) and State of Piaui (Gregorin et al. 2008) (black squares); and the new records in the Campo Lourdes and Nhumirim farms (white circles), in the State of Mato Grosso do Sul (MS), Brazil (this study). Dashed line indicates the Pantanal floodplain. 
occur in patchy forest landscapes, in addition to other types of forests (Handley Jr. 1976, Vehrencamp et al. 1977, Emmons \& Feer 1997, Sampaio et al. 2003, Vargas-Espinoza et al. 2004). The implications of the two new records presented here indicate that further, widespread bat inventories are still necessary in the Pantanal and the surrounding regions (Longo et al. 2007, Cáceres et al. 2008, Tomás et al. 2010).

\section{Acknowledgements}

To André Lima for help in the field; to Campo Lourdes farm owners for logistic support; to anonymous referees for helpful comments on the manuscript; to Ministério de Ciência e Tecnologia, Centro de Pesquisa do Pantanal (process 2008/COO/13), and Fundação de Apoio ao Desenvolvimento do Ensino, Ciência e Tecnologia do Estado de Mato Grosso do Sul (process 41/100.070/2004) for financial support; to Empresa Brasileira de pesquisa Agropecuária for financial and logistic support (process SEG-02.07.50.003-02); to Conselho Nacional de Desenvolvimento Científico e Tecnológico for grants to M. Silveira, R. Munin, and E. Fischer. Bat captures and collection were carried out under IBAMA licenses 10303-1 and 10615-2007.

\section{References}

ACOSTA, L. \& AZURDUY, R. 2006. Primeras colectas del falso vampiro Vampyrum spectrum (Phyllostomidae, Chiroptera) en el sector sur del bosque seco chiquitano, Santa Cruz, Bolívia. Kempffiana 2(1):119-126.

AGUiRRE, L., MANTILlA, H., MILLER, B. \& DÁVALOS, L. 2008. Vampyrum spectrum. In IUCN 2010. IUCN Red List of Threatened Species. Version 2010.4. www.iucnredlist.org (last accessed 25/01/2011).

ARAUJO, A.C. \& SAZIMA, M. 2003. The assemblage of flowers visited by hummingbirds in the "capões" of Southern Pantanal, Mato Grosso do Sul, Brazil. Flora 198(6):427-435.

BERNARD, E. 2001. Species list of bats (Mammalia, Chiroptera) of Santarém area, Pará state, Brazil. Rev. Bras. Zool. 18(2):455-463.

BONATO, V., FACUREAND, K.J. \& UIEDA, W. 2004. Food habits of bats of subfamily Vampyrinae in Brazil. J. Mamm. 85(4):708-713.

CÁCERES, N.C., CARMIGNOTTO, A.P., FISCHER, E. \& SANTOS, C.F. 2008. Mammals from Mato Grosso do Sul, Brazil. Check List 4(3):321-335.

DISCHER, D.S., BERNARDE, P.S \& FACURE, K.G. 2009. Mammalia, Chiroptera, Phyllostomidae, Vampyrum spectrum (Linnaeus, 1758): first record for the state of Rondônia, Brazil, and new prey records. Check List 5(3):394-395.
EISENBERG, J.F. \& K.H. REDFORD. 1999. Mammals of the Neotropics. The central Neotropics: Ecuador, Perú, Bolivia, Brazil. The University of Chicago Press, v.3, 609p.

EMMONS, L.H. \& FEER, F. 1997. Neotropical rainforest mammals: a field guide. University of Chicago Press, Chicago.

GARDNER, A.L. 2007. Mammals of South America: marsupials, xenarthrans, shrews, and bats. Chicago, University of Chicago Press, 669p.

GREGORIN, R., CARMIGNOTTO, A.P. \& PERCEQUILLO, A.R. 2008. Quirópteros do Parque Nacional da Serra das Confusões, Piauí, nordeste do Brasil. Chirop. Neotr. 14(1):366-383.

HANDLEY Jr., C.O. 1976. Mammals of the Smithsonian Venezuelan Project. Brigham Young Univ. Sci. Bull. Biol. Ser. 20:1-89.

LONGO, J.M., FISCHER, E., CAMARGO, G. \& SANTOS, C.F. 2007. Ocorrência de Vampyressa pusilla (Chiroptera, Phyllostomidae) no Pantanal sul. Biota Neotrop. 7(3): http://www.biotaneotropica.org.br/ v7n3/pt/abstract?short-communication+bn02407032007.

NAVARRO, D. \& WILSON, D.E. 1982. Vampyrum spectrum. Mamm. Spec. 184:14.

NOGUEIRA, M.R., PERACCHI, A.L. \& MORATELLI, R. 2007. Subfamília Phyllostominae. In Morcegos do Brasil (N.R. Reis, A.L. Peracchi, W.A. Pedro \& I.P. Lima, ed.). Nélio Roberto dos Reis, Londrina, p.61-97.

NOWAK, R.M. 1994. Walker's bats of the world. The Johns Hopkins University Press, Baltimore.

SAMPAIO, E.M., KALKO, E.K.V., BERNARD, E., RODRÍGUEZHERRERA, B. \& HANDLEY Jr., C.A. 2003. A biodiversity assessment of bats (Chiroptera) in a tropical lowland rainforest of central Amazonia, including methodological and conservation considerations. Stud. Neotrop. F. Environ. 38(1):17-31.

TOMÁS, W.M., CÁCERES, N.C., FISCHER, E., MOURÃO, G. \& CAMPOS, Z. 2010. Mammals in the Pantanal wetland, Brazil. In The Pantanal ecology, biodiversity and sustainable management of a large neotropical seasonal wetland (W.J. Junk, C.J. Da Silva, C. Nunes da Cunha \& K.M. Wantzen, ed.). Sofia-Moscow, Pensoft Publishers, p.563-595.

VARGAS-ESPINOZA, A., AGUIRRE, L.P., SWARNER, M., EMMONS, L. \& TERAN, M. 2004. Distribución de Vampyrum spectrum em Bolivia y comentarios sobre su estado conservación. Ecol. Bolivia 39(2):46-51.

VEHRENCAMP, S.L., STILES, F.G. \& BRADBURY, J.W. 1977. Observations on the foraging behavior and avian prey of the neotropical carnivorous bat, Vampyrum spectrum. J. Mamm. 58(4):469-478.

VIEIRA, C.O. 1955. Lista remissiva dos mamíferos do Brasil. Arq. Zool. Est. São Paulo 8(11):341-474. 